\title{
Resolusi Sengketa Kolektif Di Bidang Pertanahan Dalam Perspektif Hukum Dan Sosial $\theta_{t .}$ \\ Muhammad Arif Setiawan
}

\section{Abstrak}

There are various choice of alternative communal dispute resolution modees in land dispute. In fact, the implementation of positive legal approach is not the only instrument to settle the dispute. Sometimes, the positive legal opproach may. raise opposition which triggers a stringent measures which come from the marginal society and come from the authority holders.

\section{Pendahuluan}

Persengketaan di bidang pertanahan dan pemukiman yang bersifat kolektif semakin nampak terbuka sejak awal era reformasi. Yang dimaksud dengan persengketaan kolektif adalah persengketaan yang tidak bersifat individual, atau antar individu dalam suatu kelompok tertentu di masyarakat. Persengketaan yang bersifat kolektif terjadi antara kelompok masyarakat yang termasuk dalam kelompok masyarakat marjinal yang miskin dan lemah dalam penguasaan akses sumber daya hukum, politik, ekonomi dan kekuasaan berhadapan dengan Pemerintah atau pengusaha atau investor yang mempunyai akses penguasaan sumber daya hukum, politik, ekonomi, dan kekuasaan yang lebih kuat. Di Indonesia persengketaan di bidang pertanahan dan pemukiman yang bersifat kolektif pada awalnya, ketika masih berada di bawah pengaruh kekuasaan rezim Orde Baru, ibarat fenomena "gunung es" di tengah lautan. Yang nampak hanya puncaknya saja, tetapi sebenarnya di bawahnya tersimpan potensi yang sangat kuat untuk menjadi konflik yang sangat besar yang dapat "meledak" sewaktuwaktu apabila ada pemicunya.

Pada waktu Orde Baru sebenarnya sudah ada beberapa kasus konflik kolektif di bidang pertanahan yang terbuka, seperti kasus tanah Cimacan, Jonggol, dan Kedung Ombo, juga beberapa kasus perebutan lahan perkebunan antara petani penggarap dengan pemilik hak guna usaha yaitu PT. Perkebunan PT. Perkebunan (PTP-PTP) seperti kasus Jenggawah, Warga Wonosari Semarang (pensiunan karyawan PT. Perkebunan XV dan $\mathrm{XVI)}$ melawan warga yang merasa tanahnya diambil secara tidak sah yang dalam hal ini diwakili oleh Genderuwo (Gerakan Demokrasi Rakyat Untuk Tanah Wonosari), kasus Pagilaran dan lain sebagainya, demikian juga 
proses penggusuran pemukiman-pemukiman liar di perkotaan. Meskipun beberapa contoh kasus yang telah terbuka sejak rezim ORBA, namun ternyata banyak yang belum bisa diselesaikan sampai sekarang ini, atau kalaupun ada yang sudah selesai ternyata hasilnya berakhir dengan kisah memilukan bagi kelompok masyarakat marjinal. Kelompok masyarakat marjinal akan selalu kalah jika berhadapan dengan Pemerintah atupun pengusaha/investor.

Harian Kompas ${ }^{1}$ pernah melaporkan data dari Litbang Kompas mengenai fenomena maraknya persengketaan lahan yang bersifat kolektif yang terbuka semenjak tahun 1998 sampai 2001. Meskipun dilaporkan secara ringkas, namun karena dibuat secara sequences nampaknya cukup dapat memberikan gambaran bahwa persengketaan lahan yang bersifat kolektif telah demikian marak.

Apabila selama masa ORBA masyarakat tidak berani melawan (terutama dalam arti perlawanan fisik) pihak Pemerintah atau pengusaha, namun tidak demikian halnya yang terjadi pada era reformasi. Bentuk-bentuk perlawanan fisik yang diwujudkan dalam tindakan kekerasan, ataupun pengambilalihan penguasaan (pendudukan) tanah-tanah yang dianggap hak milik warga masyarakat secara paksa telah banyak terjadi secara terangterangan.

Di beberapa daerah di tanah air dilaporkan telah terjadi berbagai aksi pengambilan aset dan kekayaan alam daerah oleh masyarakat setempat secara demikian marak sebagaimana yang dapat dibaca dalam tabel berikut ini:2

Tabel 1

\begin{tabular}{|c|c|c|}
\hline No & Waktu & Kasus \\
\hline 1. & Mei 1998 & $\begin{array}{l}\text { Tidak lama berselang setelah jatuhnya Soeharto dari kursi } \\
\text { kepresidenan, rakyat memagari dan menguasai lahan perkebunan } \\
\text { karet PT. Bukit Jonggo! Asri (PT.BJA) milik Bambang Triharmodjo } \\
\text { anak Soeharto seluas } 2.165 \text { ha. PT. BJA merencanakan } \\
\text { membangun kota mandiri di atas lahan tersebut. }\end{array}$ \\
\hline 2. & November 1998 & $\begin{array}{l}\text { Masyarakat Kecamatan Muara Pahu dan Jempang Kabupaten } \\
\text { Kutai, Kalimantan Timur, menduduki base camp perkebunan kelapa } \\
\text { sawit milik PT. London Sumatera Grup (Lonsum) seluas } 16.500 \\
\text { ha. Masyarakat menuduh PT. Lonsum beroperasi illegal karena } \\
\text { belum mengantungi izin pelepasan kawasan hutan dan hak guna } \\
\text { usaha (HGU). }\end{array}$ \\
\hline 3. & $\begin{array}{l}\text { 13 Desember } \\
1998\end{array}$ & $\begin{array}{l}\text { Terjadi aksi pembabatan tanaman tebu milik H. Soewardi dan pabrik } \\
\text { gula Semboro oleh warga Sukorejo, Kalurahan Karangrejo, } \\
\text { Kecamatan Sumber sari, Jember, Jawa Timur. Lahan seluas } 354 \text { ha }\end{array}$ \\
\hline
\end{tabular}

${ }^{1}$ Kompas, Minggu, 11 November 2001, him.32. "Merebut Warisan Leluhur" Teks dari BI Purwanti, Libang Kompas.

${ }^{2}$ Kompas, "Merebut Warisan Leluhur' ibid. hlm.32. Tabel disusun berdasarkan laporan harian Kompas tersebut. 
Setiawan. Resolusi Sengketa Kolektif Di Bidang Pertanahan...

\begin{tabular}{|c|c|c|}
\hline No & Waktu & Kasus \\
\hline & & $\begin{array}{l}\text { itu adalah sengketa antara warga dengan pemilik lahan yaitu Puskopad } \\
\text { (Pusat Induk Koperasi TNI AD), Kodim, dan Batalyon. }\end{array}$ \\
\hline 4. & 9 April 1999 & $\begin{array}{l}\text { Massa Desa Suci dan Kemiri_di Kecamatan Panti Jember, Jatim, } \\
\text { menduduki perkebunan kopi milik Perusahaan Daerah Perkebunan } \\
\text { (PDP) Ketajek. Massa menuduh Pemda merekayasa pemilikan lahan } \\
\text { sehingga lahan yang dulunya milik Belanda berubah menjadi HGU } \\
\text { PDP Ketajek. Polisi menghalau keluar dengan kekerasan sehingga } \\
10 \text { orang mengalami luka tembak. }\end{array}$ \\
\hline 5. & 28 Juni 1999 & $\begin{array}{l}\text { Ribuan warga Kecamatan Permata Intan, Kabupaten Barito Utara, } \\
\text { Kalteng, menyerbu dan menguasai areal pertambangan emas PT. } \\
\text { Indo Muro Kencana (PT. IMK). Warga marah karena PT IMK main } \\
\text { gusur terhadap kapling tanah adat. }\end{array}$ \\
\hline 6. & 19 April 2000 & $\begin{array}{l}\text { Jalan umum ke lokasi tambang emas PT. Kelian Equatorial Mining } \\
\text { (PT.KEM) di Kutai Barat, Kaltim, diblokir masyarakat setempat. Aksi } \\
\text { pemblokiran berkaitan dengan tuntutan ganti rugi tanah, bangunan, } \\
\text { dan tanaman tumbuh milik warga }\end{array}$ \\
\hline 7. & 5 Juni 2000 & $\begin{array}{l}\text { Sekitar 200-300 petani desa Sidorejo, Kecamatan Doko, Kabupaten } \\
\text { Blitar, Jatim, menguasai dan menebang habis } 100 \text { ha tanaman cengkeh } \\
\text { di kebun Branggah, Banaran, milik PTP Nusantara Blitar. Petani merasa } \\
\text { berhak atas tanah PTPN. Polisi kemudian merebut lahan itu dengan } \\
\text { kekerasan sehingga } 2 \text { warga tewas tertembak, dan } 16 \text { luka-luka. }\end{array}$ \\
\hline 8. & 15 Juni 2000 & $\begin{array}{l}\text { Warga Ratatotok, Kecamatan Belang, Kabupaten Minahasa, Sulut, } \\
\text { memblokir jalan masuk ke penambangan emas PT. Newmont } \\
\text { Minahasa Raya (PT. NMR). Warga menggugat atas ganti rugi tanah } \\
\text { yang hanya dihargai PT. NMR sebesar Rp } 250,- \text {-meter persegi. } \\
\text { Sebelumnya Pemda Minahasa menggugat PT NMR sebesar Rp } 61,5 \\
\text { Milyar untuk retribusi galian golongan C yang belum dibayar. Selama } \\
\text { ini mereka yang seharusnya menjadi pemilik, justru lebih banyak "gigit } \\
\text { jari" karena kekayaan alam mereka lebih banyak dikuasai dan dinikmati } \\
\text { oleh orang lain. }\end{array}$ \\
\hline
\end{tabular}

Hasil jajak pendapat pembaca harian Kompas tanggal 30 Agustus 2001 dapat memberikan gambaran mengenai sikap masyarakat terhadap fenomena persengketaan pertanahan kolektif antara masyarakat dengan negara dan pengusaha. Menurut para responden muncuinya persengketaan tersebut diakibatkan oleh sikap Pemerintah Pusat yang tidak adil dalam melakukan pembagian potensi dan hasil kekayaan alam di Daerah. $67,8 \%$ responden berpandangan bahwa pemerintah pusat bertindak tidak adil terhadap pembagian potensi dan hasil kekayaan alam di daerah. Hanya 18,8\% 
responden yang berpandangan bahwa Pemerintah Pusat telah bertindak adil. ${ }^{3}$

Secara sangat menarik, Farida telah mempetakan perbedaan pola dan sifat konflik pertanahan yang terjadi pada masa Orde Lama dengan Orde Baru. Apabila pada saat Orde Lama persengketaan lahan biasanya bersifat horisontal antar sesama petani, kemudian sebagai akibat perubahan politik agraria pada masa Orde Baru maka sifat konflik tersebut berubah menjadi bersifat vertikal yaitu antara rakyat dengan penguasa atau pemilik modal. Demikian juga jika pada masa Orde Lama, persengketaan pertanahan biasanya bersifat telanjang dan langsung, maka pada masa Orde Baru selain bersifat telanjang juga terdapat sistemik dan struktural sehingga sulit dilihat.

Politik pertanahan pada masa sesudah kemerdekaan yaitu pada masa pemerintahan Soekarno, khususnya yang berkaitan dengan masalah redistribusi tanah melalui program land reform menurut Noer Fauzi ${ }^{\dagger}$ sebenarnya telah berjalan cukup baik karena berdasarkan Undang Undang Pokok Agraria (UUPA) tahun 1960, para petani mempunyai sumber daya hukum untuk memperjuangkan hak kepemilikan atas tanah. Program land reform selama empat tahun dihitung dari keluarnya UUPA tahun 1960 pada tahap pertama telah berhasil dilakukan redistribusi tanah seluas 295.565 ha, dan pada tahap kedua seluas
152.502 ha. Pada masa itu kepentingan petani kecil menjadi perhatian utama, sehingga jika terjadi konflik pertanahan maka petani kecil masih mempunyai kemungkinan untuk dimenangkan. Dengan kenyataan itu, kemudian ia berani mengatakan bahwa pada saat Orde Lama politik agrarianya justru lebih bersifat kerakyatan.

Namun seiring dengan pergantian rezim dari Orde Lama ke Orde Baru - ternyata politik agrarianya juga terjadi perubahan. Arah politik agraria Orde Baru ternyata tidak berpihak kepada para petani namun terlihat lebih berorientasi pada kepentingan negara yang dalam prakteknya sering dikuasai oleh para pemilik modal. Metode penyelesaian konflik di bidang pertanahan yang terjadi antar masyarakat petani disatu pihak melawan negara atau pemilik modal tidak jarang dilakukan dengan pendekatan keamanan. Menurut Noer Fauzi, untuk meredam aksi-aksi protes yang menyangkut pertanahan dari para petani, Orde Baru menerapkan politik otoritarian, yang seringkali untuk mendukung keberhasilannya di back up oleh kekuatan militer. $^{6}$

Konflik persengketaan kolektif di bidang pertanahan dan pemukiman tidak hanya antara masyarakat yang tinggal di kawasan pedesaan dan atau perkebunan, namun juga terjadi di kota-kota besar. Sudah menjadi sajian berita setiap hari mengenai bagaimana

\footnotetext{
${ }^{3}$ Kompas, Minggu, 11 November 2001.

${ }^{4}$ Farida, Mencari SolusiMasalah Sengketa Tanah, dikutip dari www.arupa.or.id/publications/jumal Psdh12/Mencari Solusi.htm. 25 November 2001. Hlm.2. Sayang sekali Farida tidak menjelaskan apa yang dimaksud dengan istilah konflik yang bersifat telanjang, sistemik dan struktural Meskipun penjelasan selanjutnyayang juga telah dikutipkan penulis dapat menjelaskan maksud istilah tersebut. -

${ }^{5}$ Farida, ibid. HIm. 1.

${ }^{6}$ Farida, ibid. hlm.1
} 
pemerintah daerah menangani persoalan pemukiman/hunian liar di kota-kota besar. Bulan November dan Desember 2001 harian Kompas banyak menurunkan berita mengenai pelaksanaan penertiban hunian liar dan tempat usaha liar di banyak tempat di Jakarta.

Sebagaimana yang terjadi pada kasuskasus persengketaan tanah kolektif yang terjadi di wilayah perkebunan yang berakhir dengan kekalahan pihak masyarakat, yang terjadi dalam kasus penertiban hunian liar juga kurang lebih sama, yaitu rakyat berada pada posisi lemah sehingga kalah apabila berhadapan dengan pihak Pemerintah.

Dari beberapa contoh kasus konflik kolektif di bidang pertanahan biasanya akan terjadi suatu kondisi berupa "legal gap $p^{n 7}$ yaitu adanya perbedaan pemahaman mengenai hukum positif tertentu antara rakyatmasyarakat yang awam hukum, dengan penguasa atau para pemilik modal yang biasanya telah "melek" hukum atau faham hukum.

Dalam kasus-kasus sengketa di bidang pertanahan, rakyat atau masyarakat awam hukum biasanya hanya mendalilkan pada pemahaman kepemilikan karena mendapatkan dari warisan nenek moyang yang telah turun temurun antar generasi, karena dalam persepsinya proses penerusan penggarapan tanah secara terus menerus tersebut sebenarnya sudah merupakan bukti indikasi adanya hak kepemilikan. Sedang di pihak pemerintah atau para pemilik modal, yang sudah mengenal sistem administrasi kepemilikan yang modern, pembuktian kepemilikan hak atas tanah didasarkan pada sertifikat yang diberikan oleh otoritas kekuasaan (negara)-yang dalam persepsi para petani justru seringkali dicurigai merupakan hasil korupsi, kolusi dan nepotisme (KKN).

Dalam masyarakat agraris seperti Indonesia ini, masalah persengketaan tanah dapat menjadi sangat sensitif bagi rakyat kebanyakan dan merupakan salah satu faktor pemicu keresahan bahkan kerusuhan sosial. Ada peribahasa dalam bahasa Jawa "Sedumuk bathuk senyari bumi", yang dapat berarti bahwa setiap gangguan terhadap kepemilikan hak atas tanah bisa memicu terjadinya pertumpahan darah. Oleh karena itu adanya legal gap dalam masalah pembuktian hak kepemilikan atas tanah menjadi penting untuk dikaji secara seksama.

Bagaimana meniadakan legal gap tersebut? Tepatkah masalah tersebut diselesaikan dengan menjalankan hukum positif yang mengatur masalah pertanahan? Bagi mereka yang menganut faham positivisme-legisme yang sangat percaya bahwa salah satu tujuan hukum adalah tercapainya kepastian hukum, tentu sangat yakin akan keampuhan dan ketepatan hukum positif jika dipakai untuk menyelesaikan konflik di bidang pertanahan yang diakibatkan oleh terjadinya legal gap tersebut. Dengan hukum positif setidak-tidaknya akan tercapai kepastian hukum. Namun demikian pendekatan tersebut tentu akan melemahkan posisi masyarakat marjinal (petani) yang pada umumnya tidak mempunyai akses yang memadai untuk menguasai hak atas tanah yang menghendaki adanya bukti formil yang diperkenalkan oleh hukum pertanahan modem yang dinamakan dengan sertifikat hak kepemilikan atas tanah apapun jenis haknya.

${ }^{7}$ Istilah yang diperkenalkan dipakai oleh Sutandyo W. 
Hasilnya sudah dapat diduga bahwa para petani pasti akan berada pada pihak yang kalah karena mereka tídak mempunyai : dokumen kepemilikan yang diakui oleh hukum positif. Oleh karena itu nampaknya perlu solusi lain yang bersifat alternatif untuk meniadakan legal gap di' bidāng pertanahàn yang menyebabkan terjadinya konflik di bidang pertanahan yang bersifat kolektif.

'Tulisan ini akan mengkaji masalah persengketaan kolektif di bidang pertanahan" dan bagaimana solusi untuk menyelesaikan persengketaan tersebut :dalam perspektif hukum dan sosial. Dengan memahami trend kasus-kasus kōnflik pertanahan yang bersifat kolektif termasuk bagaimana model penyelesaian kasusnya, baik yang terjadi di tingkat lokal ataupun yang terjadi di negara lain; diharapkan dapat menjadi bahan inspirasi bagi pengambil kebijakan di bidang pertanahan untuk menyelesaikan kasus konflik. pertanahan kolektif baik yang bersifat kasuistis ataupun untuk melakukan reformasi peraturan di bidang pertanahan yang dapat mengambil. aspirasi dari trend pemahaman masyarakat?

- Kasus persengketaan kolektif di bidang pertanahan dan pemukiman yang bersifat lokal ${ }^{-}$ diambilkan dari beberapa perkara yang telah diselesaikan oleh Pemerintah Daerah Jawa: Tengah, yaitu kasus yang terjadi di Desa. Gedangan, ${ }^{\prime}$ Kelet Donorejo dan Benteng Portugis di Jepara. Sedang kasus yang terjadi. di negara lain diambilkan dari kasus yang terjadi di Recife Brazil berdasarkan hasil studi yang dilakukan oleh Boaventura De Sousa Santos di Pasargada dan Recife Brazil.. .

\section{Perjjuangan Hukum Kaum Miskin di Recife untuk Mendapat Hak Atas Tanah:}

Sekitar tahun 1970, Santos telahmelakukan penelitian di daerah Pasargada. Pasargada adalah nama fiktif yang diberikanoleh Santos untuk daerah penelitiannya berupaperkampungan hunian liar yang. sangat besar. di Brazil, yang dihuni oleh sebagian besar penduduk yang sangat rendah tingkat pendidikan dan pengetahuannya, dengan. tingkat konflik sosial dan hukum yạng juga" demikian besar.

Berdasarkan hasil penelitian Santos di Pasargada yang' berkaitàn. dengan penyelesaiàn konflik pertanahan-hunian antar sesama penduduk Pasargada sendiri ataupun antara penduduk Pasargada melawan Pemerintah menunjukkan bahwa hukum negara ternyata tidak berdaya menghadapi sikap masyarakat yang lebih mengedepankan rasa keadilan rakyat dibandingkan dengan rasa keadilan menurut ukuran hukum formal.

Pada waktu itu (tahun 1970) Brazil dapat' dimasuukkan dalam kategori periode rezim birokrat otoriter, yaitu suatu periode represi yảng bersifat brutal yang dilakukan oleh aparat tentara pemerintah sebagai akibat dari adanya anggapan bahwa ukuran-ukuran kebijakan masyarakat perkotaan dan perkembàngan" masyarakat perkotaan sebagai suatu karakter yang bersifat represif. Dengan demikian tindakan untuk melakukan penggusuran atau. penghapusan atas sebagian besar perkampungan dengan penghuni liar dapat dilakukan dengan mobilisasi polisi dan

$\therefore \quad{ }^{8}$ Boaventura De Sousa Santos, Toward a New Common Sense: Law, Science, and Politics in The Paradigmatic Transition, London GreatBritain: Routledge, 1995. Mengingat seringnya dikutip maka penunjukan sumber buku Santos tersebut selanjutnya hanya akan disebut sebagai "Santos". 
angkatan bersenjata. Golongan-golongan umum dalam masyarakat di disorganisasi dan diisolasi, sehingga mereka berada dalam posisi bertahan. Perkembangan hukum di Pasargada adalah sebagai sumber hukum internal dari penguasaan sumber-sumber yang langka (dalam hal ini adalah tanah dan rumah).

Periode Pasargada yang diuraikan Santos sebenarnya adalah analisis mengenai time space dari hukum lokal tetapi juga menyangkut mengenai time-space dari hukum nasional. Adalah sangat menarik apabila membaca uraian hasil penelitian mengenai kasus-kasus peralihan hak atas tanah atau rumah beserta metode penyelesaian sengketa yang dipakai untuk menyelesaikan konflik.

Berbeda dengan fokus studi di Pasargada, penelitian Santos di Recife Brazil sepuluh tahun kemudian menunjukkan beberapa karakteristik yang berbeda karena legal time-spacenya lebih menuju pada legal time space lokal-nasionaldan transnasional. Hal ini diakibatkan oleh masuknya gereja dalam medan persengketaan pertanahan. Gereja masuk dengan memperkenalkan suatu pendekatan teologi yang khas muncul di Amerika Latin yaitu teologi pembebasan (liberation theology). ${ }^{9}$

Daerah Metropolitan Recife adalah salah satu dari sembilan kutub makro regional di Brazil. Jumlah penduduk pada waktu diadakan

${ }^{9}$ Skema dibuat Fr. Wahono Nitjpawiro berdasarkan pendapat Robert McAfee Brown (1980), Gustavo Guiterrez, Atlanta, Jhon Knox Press, hlm.43-44. Tesis Fr. Wahono Nitipawiro, Teologi Pembebasan: Sejarah, Metode, Praksis, dan Isinya, Yogyakarta:LKIS, 2000, hlm. 147.

Skema Perbedaan antara Teologi Barat dan Teologi Pembebasan Teologi Barat Teologi Pembebasan

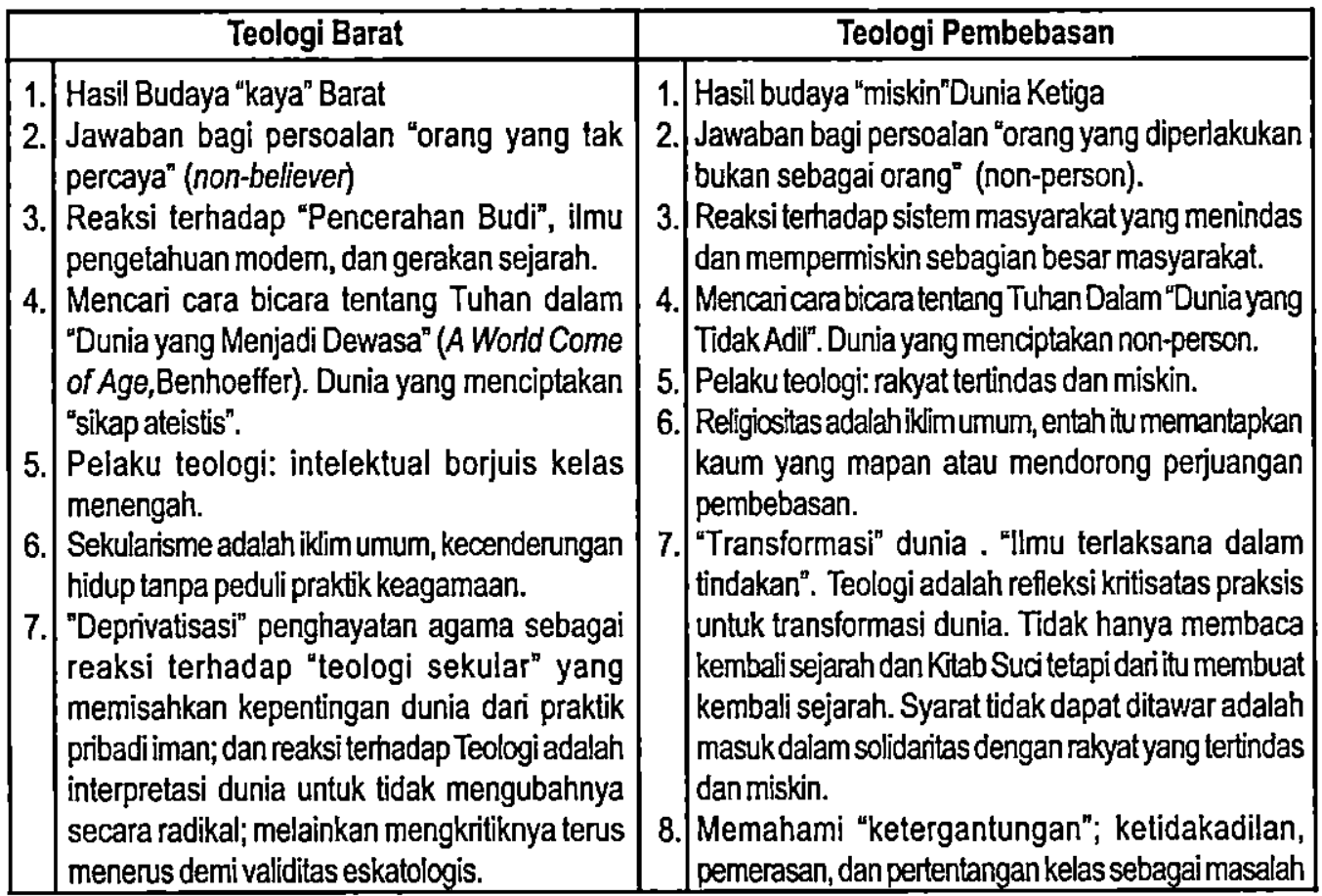


penelitian sebanyak 2,2 juta, dan sebanyak $58 \%$ diantaranya tinggal di kota Recife. Menurut statistik pada tahun $1976,76 \%$ dari. seluruh populasi bekerja pada sektor ketiga yaitu sektor informal. Lebih dari $68 \%$ populasi masyarakat kota ternyata tinggal di perkampungan-perkampungan penghuni liar. ${ }^{10}$

Struktur ruang kota di Recife dibentuk oleh dua faktor utama produksi yaitu pertama adalah ekonomi tebu dan sistem perkebunan. Kedua, berhubungan dengan ciri-ciri ekologi dari tanah yang terletak di pesișir di antara muara dua sungai yang dipengaruhi oleh pasang-surut air laut. Tanah tersebut milik negara, dan konsesi_atas hak menggunakan. tanah melalui kontrak terus menerus diikat secara tradisional dengan politik lokal, pengaruh sosial, dan administratif. Berdasarkan sejarah Recife diketahui bahwa ada dua perbuatan yang saling berkaitan yaitu antara kehilangan dokumen hukum tanah dan pembuatan dokumen tanah yang palsu merupakan kejadian yang biasa terjadi.

Faktor lain yang turut andil dalam terjadinya ambiguitas dalam status hukum atas tanah ini adalah: pertama, orang miskin dijijnkan untuk membangun gubuk-gubuk di: atas tanah yang tidak tergarap, mereka kemudian akan menciptakan tanah garapan, namun demikian di kemudian hari mereka akan dikeluarkan dari area tanah garapan tersebut, lalu para pemilik hak atas tanah tersebut diuntungkan karena tanah tersebut sudah siap untuk dipakai produksi. Hal inilah yang menjadi salah satu alasan terjadinya - persengketaan, masyarakat miskin di kota tersebut biasanya akan mendaku telah memiliki hak resmi atas tanah yang mereka garap karena mereka atau nenek moyang mereka telah miengelola tanah garapan: ${ }^{11}$

Sebagai akibat dari langkah spekulasi dalam perdagangan tanah dan arus migrasi ke kota ternyata telah menciptakan situasi kelangkaan tanah di Recife. Tingginya tingkat. kepadatan penduduk telah melukai operasi internal sistem hukum informal. Para penduduk miskin menghadapi situasi dimana mereka harus membayar sewa gubuk di luar kemampuan membayar mereka. Hal inilah yang menjadi faktor pendorong bagi mereka untuk menyerbu dan menguasai tanah-tanah yang tidak digunakan. ${ }^{12}$

Berikut akan diuraikan secara ringkas tiga contoh kasus konflik kolektif di bidang pertanahan - hunian dikota Recife dari buku Santos tersebut, yaitu: The Children's Town, The Skylab, dan The Peasants Town.

\section{The Children's Town ${ }^{13}$}

Pada Oktober 1979 sebanyak tiga ratus keluarga melakukan invasi ke sebuah bidang

\begin{tabular}{|l|l|l|}
\hline 8. & $\begin{array}{l}\text { "Abstraksi dan generalisasi", seakan-akan } \\
\text { masalah sekularisme adalah masalah dasar } \\
\text { semua orang, termasuk mereka yang di Dunia } \\
\text { Ketiga. }\end{array}$ & $\begin{array}{l}\text { dasar Dunia Ketiga; juga secara struktural masalah } \\
\text { seluruh dunia. }\end{array}$ \\
\hline
\end{tabular}

${ }^{10}$ Santos, hlm. 378-379.

11 Santos, him. 380.

12 Santos, him. 380-381.

${ }^{13}$ Santos, hlm.381-382. 
pertanahan seluas tiga hektar yang tidak dipakai selama tiga puluh tahun. Tanah tersebut sebenarnya milik sebuah perusahaan kosmetika di Sao Paulo. Ketika pemilik tanah mengetahui kejadian tersebut, ia menyewa pengacara di Recife untuk memperkarakan pihak penyerbu. Untuk mendapatkan nama para penyerbu tanah - karena khawatir penduduk akan menyembunyikan identitas mereka - pengacara melakukan penipuan dengan mengecoh penduduk bahwa nama mereka akan diperlukan untuk memberikan ganti kerugian.

Perkara tersebut dijadikan menjadi satu. Keputusan hakim diberikan pada akhir pekan dan langsung dieksekusi pada hari itu-juga. Ketika para penduduk mencoba untuk mempertahankan diri dari pengusiran, mereka diberi perlakuan brutal. Dukungan dari luar tidak berhasil didapatkan karena hari itu adalah akhir pekan (libur).

\section{The Skylab ${ }^{14}$}

Pada hari Jum'at malam di bulan Juli 1979 , lebih dari dua ratus keluarga menyerbu areal lahan seluas lima hektar yang dimiliki oleh pengembang real estate lokal yang mempunyai hubungan kuat dengan borjuis tanah tradisional. Ketika pemilik tanah mengetahui hal itu, ia berusaha meminta bantuan Sekretaris Negara bidang Keamanan Publik agar melakukan intervensi terhadap polisi untuk mengusir para penyerbu tanah, namun mereka diminta menunggu sampai hari senin. Usaha mereka untuk membujuk sendiri para penyerbu agar meninggalkan lokasi temyata tidak membuahkan hasil.

Hari senin pagi pemilik tanah dengan dikawal beberapa mobil polisi mendatangi lokasi dengan membawa dua buah truk yang berisi dua puluh pekerja. Mereka merusak beberapa gubuk yang telah dibangun. Para pendudük berusaha bertahan di gubug yang masih tersisa. Para penduduk kemudian meminta bantuan kantor hukum dari Komisi Keadilan dan Perdamaian yang didirikan oleh Arcbishop D. Helder Camara.

Perundingan antara kedua pihak menghasilkan kesepakatan bahwa para penduduk dan pemilik tanah sepakat untuk terikat dalam kontrak penyewaan tanah secara terus menerus selama periode maksimal 5 tahun.

\section{The Peasant Town ${ }^{15}$}

November 1979 , beratus-ratus penduduk melakukan invasi ke dalam areal pertanahan seluas empat belas hektar milik perusahaan pemerintah di bidang perlistrikan. Melihat kenyataan ini perusahaan melakukan langkah pengusiran secara hukum. Mereka mendapatkan 135 nama para penyerbu yang diperoleh melalui cara memperdayai seperti yang pernah ditempuh dalam kasus The Children Town.

Ketika penduduk sadar bahwa mereka diperkarakan di pengadilan, mereka berkumpul di gereja, lalu meminta bantuan Komisi Keadilan dan Perdamaian. Pendeta gereja menasehati agar mereka tidak memberikan identitas mereka dalam keadaan bagaimanapun juga. Dengan cara ini

\footnotetext{
${ }^{14}$ Santos, him. 381-382.

${ }^{15}$ Santos, hlm. 383-384.
} 
diharapkan ada hambatan teknis hukum bagi para pengacara pemilik tanah yang akan memperkarakan mereka. Para pengacara gereja kemudian mulai ikut menangani masalah ini.

Ketika sidang berlangsung para penduduk ikut hadir-dan memenuhi ruang sidang dan halaman pengadilan. Mereka menyanyikan lagu-lagu agama dan menggelar spanduk-spanduk seperti "Who bought the land from God?" dan "The people united won't be defeated". Sidang kemudian ditunda oleh hakim. Penduduk kemudian berjalan kaki ke kantor Gubernur dan Sekretaris Negara Bidang Perumahan. Dalam pertemuan dengan para pejabat tersebut para pengacara gereja meminta persidangan ditunda selama tiga puluh hari dengan harapan untuk memperoleh solusi ekstra judisial.

Pada akhir persidangan, setelah putusan disampaikan kepada pihak-pihak, para penduduk tetap menolak pengusiran. Kalaupun ada pengusiran berdasarkan putusan pengadilan, maka hal itu hanya akan berakibat kepada 135 nama yang telah diperkarakan, selebihnya yang jumlahnya ribuan justru tidak akan terpengaruh oleh keputusan pengadilan tersebut. Para pengacara penduduk kemudian mengajukan permohonan banding (appeal) berdasarkan landasan konstitusional dengan alasan utama kepemilikan hak pribadi seharusnya menghasilkan hak sosiopolitik bagi warga untuk mendapatkan perumahan yang layak. Pada akhirnya terjadi kejutan karena permohonan banding tersebut dikabulkan, dan eksekusi tersebut ditangguhkan.

\section{Penyelesaian Konflik Kolektif di Bidang Pertanahan di Jawa Tengah}

Apabila berita-berita mengenai penggusuran kawasan-kawasan hunian atau perdagangan (umumnya kaki lima) yang dianggap liar di Jakarta dilakukan dengan caracara kekerasan oleh aparat pemerintah (dalam hal ini aparat dari Dinas Ketertiban Umum Pemda DKI-ditambah unsur Polisi Pamong Praja) yang dibantu oleh Kepolisian Negara RI dianalisis dengan pendekatan hukum secara doktriner, maka hasilnya diperkirakan akan menunjukkan bahwa pemerintah sebagai pihak yang melakukan aksi penggusuran akan berada pada pihak yang kuat karena pihaknya akan mendasarkan pada alasan bahwa daerah yang di gusur adalah domain tanah negarayang berada dalam jangkauan kewenangan pemerintah, sedang pihak yang digusur berada pada pihak yang menempati tanah tersebut tanpa alas hak yang sah menurut peraturan hukum formal. ${ }^{16}$

Argumentasi apapun termasuk argumentasi yang bersifat hukum yang

${ }^{16}$ Kompas, 3 November 2001 "Jakarta Tak Menyisakan Air Mata", "Soal Pemukiman di Bantaran Kali: Kesalahan dan Kelalaian Pemda DKl", Kompas 6 November 2001 "Tanah Kembali Warga Wanasari Pesta", Kompas, 11 November 2001 "Merebut Warisan Leluhur". Kompas, 12 November 2001 "Wajah-Wajah Perempuan di Penggusuran". Kedaulatan Rakyat 14 November 2001 "Trauma Penyelesaian Kedongombo: Paguyuban Warga Justru Tak Ikut Tim Kecil", Kompas, 19 November 2001 Aparat Pemda DKI yang Korup Juga Harus Digusur", "Hentikan Penggusuran Selama Ramadhan", "Pilih Kasih Menggusur Menebar iri Hati Rakyat Kecil". Kompas, 30 November 2001 "Diserang Preman Warga Wanasari Minta Perlindungan", Kompas, 6Desember 2001 "Ibukkota Dikelola Oleh Penggusur", "Penggusuran dan Pembakaran Menjadi Ciri Khas Jakarta". 
diberikan óleh pihàk masyarakat yang digusur selalu tidak akan pernah "sambung" dengan argumentasi hukum-yang dipegang oleh pemerintah. Argumentasi hukum kaum tergusur dalam konteks hukum positif sebenarnya tidak pernah-dapat masuk dalamkualifikasi perolehan alas hak yang sah, karena biasanya mereka hanya sanggup untuk menceritakan asal muasal mereka menempati tanah tersebut, bagaimana mereka membayar uang kepada oknum aparat pemerintah dan lain sebagainya namun tidak disertai buktiotentik mengenai hak kepemilikan atau hak penguasaan yang sah menurut hukum positif. .'

Penggusuran kaum pemukim liar di. perkotaan secara paksa sebenarnyalah hanya. satu model dari beberapa model yang bisa dipilih. Demikian juga bagi masyarakat yang : akan terkena penggusuran ia juga mempunyai beberapa pilihan, apakah akan diam dan menerima' nasib begitu saja atau akan mendayagunakan segala cara untuk bertahan hidup atau bertahan untuk menguasasi atau : memanfaatkan tanah negara yang mereká.tempati. Hasil studi Santos di Pasargada dan Recife Brazil yang-secara ringkas telah pula . disinggung dalam bagian sebelum ini telah menunjukkan adanya alternatif lain yang bisa dipilih baik bagi masyarakat ataupun bagi aparat pemerintah dalam menghadapi konflik' pertanahan di perkotaan yang bersifat kolektif.

Berikut ini akan disajikan contoh konflik pertanahan kolektif antara masyarakat melawan Pemerintah dan bagaimana konflik tersebut diselesaikan. Penyajian kasus ini diharapkan dapat dipakai sebagai awal gagasan untuk menemukan inspirasi mengenai alternatif résolusi penyelesaian konflik kolektif di bidang pertanahan.

\section{Kasus Desa Gedangan ${ }^{17}$}

Desa Gedangan terletak di Kecamatan Welahan, Kabupaten Jepara, Jawa Tengah. Di salah satu bagian wilayah desa Gedangan terdapat aset tanah milik Pemerintah Propinsi Jawa Tengah dalam hal ini milik Dinas Pekerjaan Umum. (DPU) Bina Marga. Luas tanah tersebut lebih kurang dua setengah hektar $(2,5 \mathrm{Ha})$. Tanah seluas itu sampai saat . ini dipergunakan untuk keperluan:

- Sebagian, seluas lebih kurang-18.887. meter persegi sesuai dengan hasil: pengukuran oleh Kantor Pertanahan, ditempati dan didirikan bangunan-: bangunan rumah / tempat tinggal oleh masyarakat sejak lama, yang dibagi : menjadi:56 kavling tanah.

- Sisanya dimanfaatkan untuk kepentingan. umum sebagai berikut:

a. Lapangan olah raga/tanah kosong yang dikelola oleh Karang Taruna setempat, seluas lebih kurang 5.280 meter persegi.

b. Sub terminal/ terminal angkutan . $\therefore$ pedesaan, dikelola oleh Pemerintah Kabupaten-Jepara seluas 228 meter persegi.

${ }^{17}$ Kasus diámbil dari berkas-berkas kasus yang ada di Dewan Perwakilan Rakyat Daerah Tk.I Jawa Tengah. Kasus ini diperoleh atas jasa baik Sdr. Muhammad lqubal, SH. MH. Anggota DPRD Tk. I Jawa Tengah. Untuk selanjutnya kasus ini akan disebut sebagai kasus desá Gedangan: Pembáhasan atas model:masalah penyelesaian sengketakolektif di bidäng pertanahan ini dilakukan bersama-sama dengan Sdr. M. Iqbal SH.MH.dan. Dr. Mela. 
c. Jalan cadangan untuk pelebaran jalan.

Untuk tanah-tanah yang dipergunakan sebagai kepentingan umum, nampaknya tidak ada masalah bagi Pemerintah Daerah Tk. I Jawa Tengah. Yang menjadi masalah adalah tanah-tanah seluas 18.887 meter persegi yang dihuni dan didirikan bangunan oleh penduduk serta dibagi-bagi menjadi sebanyak 56 kavling oleh penduduk itu sendiri.

Warga sudah menempati tanah tersebut sejak tahun 1972. Tidak diketahui secara pasti siapa yang paling dahulu menempati areal tanah kosong milik Pemerintah tersebut, serta tidak diketahui pula dengan cara atau dengan ijin siapa mereka masuk ke dalam area tanah kosong yang menurut Pemerintah adalah bukan milik mereka, karena tanah itu sebenarnya milik negara (Pemerintah Daerah Tk.I Jawa Tengah cq DPU Bina Marga). Sudah dilakukan beberapa kali upaya untuk mengosongkan tanah tersebut namun tidak berhasil. Sejauh ini belum ada tanda-tanda pernah dilakukan upaya pemaksaan untuk mengeluarkan atau mengusir para penghuni tanah negara tersebut.

Namun demikian ternyata pihak pemilik tanah juga tidak pernah menempuh jalur hukum misalnya lewat gugatan di Pengadilan Negeri atau melalui proses pidana dengan melaporkan pendudukan tanah tanpa ijin pemilik tersebut sebagai bentuk perbuatan pidana. Yang dilakukan oleh penduduk justru upaya pendekatan jalur hukum dan politik melalui Pemerintah Kabupaten Jepara agar mereka dibantu untuk menguruskan permohonan kepemilikan hak atas tanah tersebut kepada Pemerintah Daerah Tk. I Jawa Tengah.

Meskipun mereka tidak mempunyai bukti hak kepemilikan menurut ketentuan hukum pertanahan, namun mereka mengajukan alasan bahwa mereka sudah menempati tanah tersebut selama lebih dari 25 tahun yaitu dimulai sejak tahun 1972 sehingga adalah layak jika mereka diberikan prioritas untuk memperoleh hak atas tanah tersebut.

Setelah melalui proses pemeriksaan yang cukup rumit, dengan mendasarkan pada persetujuan Dewan Perwakilan Rakyat Daerah Tk.l Jawa Tengah, Gubernur Kepala Daerah akhirnya menetapkan bahwa terhadap tanahtanah tersebut yang semula untuk kepentingan umum ditetapkan terus dijadikan untuk kepentingan umum, sedang untuk 56 kavling yang dipergunakan oleh para penghuni dapat dimiliki oleh para penghuni sepanjang mereka sanggup untuk membayar ganti kerugian kepada Pemerintah yang besamya ditetapkan sebesar Rp 22.000,00 per meter perseginya. Uang perolehan ganti rugi tersebut nantinya akan dijadikan sebagai bagian dari pendapatan daerah yang dimasukkan dalam APBD.

\section{Kasus Warga Kelet, Donorejo dan Benteng Portugis}

Status tanah di desa itu semula pada waktu penjajahan adalah milik Zending yang berkedudukan di Belanda. Sesudah kemerdekaan, berdasarkan Undang-Undang PokokAgraria No.5 Tahun 1960 tanah tersebut statusnya berubah menjadi tanah negara. Dalam perjalanannya tanah-tanah tersebut kemudian dikelola untuk keperluan rumah sakit kusta yang berada di bawah pengawasan Dinas Kesehatan Propinsi Jawa Tengah. Pada tahun 1971 tanah tersebut sudah bersertifikat dengan jenis hak Pakai selama10 tahun dan 
pada tahun 1990 Sertifikat Hak Pakai tersebut sudah diperpanjang.

Yang menjadi persoalan bagi pemerintah kemudian adalah bahwa di atas tanah yang sangat luas tersebut ternyata tidak hanya dipakai oleh Rumah Sakit Kusta milik Dinas Kesehatan Propinsi Jawa Tengah, namun sudah pula dibangun, dihuni dan dipakai oleh beberapa pihak tanpa ada dasar hak yang jelas (menurut definisi peraturan hukum tertulis). Secara umum yang memakai tanah tersebut antara lain Pemerintah Kabupaten Jepara, Yayasan BOPKRI, Yayasan AGAPE, Yayasan Gereja Kristen Injil Tanah Jawa (GKITJ), Direktorat Perhubungan Laut-untuk Navigasi, dan penduduk warga masyarakat sekitar.

Semua pihak yang telah disebutkan di atas, kecuali pihak Pemerintah Kabupaten Jepara, meskipun tidak mempunyai bukti kepemilikan menurut ketentuan hukum yang berlaku namun merasa mempunyai hak untuk mendapatkan hak kepemilikan atas tanah tersebut dengan argumentasi historis masingmasing, dan mereka juga berkeinginan untuk dapat memiliki hak atas tanah tersebut untuk dipakai sesuai dengan kepentingan masingmasing.

Pemerintah Daerah Tk.I Jawa Tengah sendiri nampaknya mengalami kesulitan untuk mengatasi persoalan tersebut karena demikian rumitnya persoalan. Namun hingga kini tidak ada indikasi dilakukannya upaya penggusuran secara paksa terhadap para penghuni atau pemakai tanah yang tidak mempunyai bukti kepemilikan, meskipun upaya untuk meminta mereka pergi secara sukarela telah sering dilakukan.

Berdasarkan pertimbangan kerumitan hükum dan sosial apabila dilakukan upaya pemaksaan untuk menggusur ataupun mengusur para penghuni yang sebenarnya tidak mempunyai bukti kepemilikan atas tanah tersebut maka dengan dukungan persetujuan DPRD - Tk.I Jawa Tengah dilakukan upaya untuk menyelesaikan konflik dengan cara pihak-pihak yang secara historis dan sosial tidak mempunyai hubungan dengan tanah tersebut secara kuat dan meyakinkan maka permohonannya akan ditolak, namun jika para pihak yang mengajukan permohonan ada kemungkinan terdapat kaitan sosial dan historis dengan tanah tersebut kemudian dilakukan pendataan secara seksama untuk nantinya akan diselesaiakan kasus demi kasus.

Pihak-pihak yang jelas telah ditolak permohonannya oleh Gubernur adalah pihak: 1) Majelis Gereja GITJ (dasar Surat Gubernur Jawa Tengah No. 593/6451 tanggal 26 Pebruari 1987.

2) Yayasan AGAPE (dasar Surat Gubernur Jawa Tengah tanggal 11 Mei 1988 No. 593/13153.

Bagi RS Kusta dan keperluan yang berkaitan dengan RS Kusta sudah jelas telah memperoleh hak pakai atas tanah tersebut. Namun bagi pihak lainnya yang menempati sebagaian dari tanah yang sebenamya semula hanya akan dipergunakan untuk keperluan RS Kusta sudah didata untuk diselesaikan dan kemungkinan akan diberikan hak atas tanah tersebut, namun belum jelas dalam bentuk dan dengan cara bagaimana proses peralihan haknya akan ditentukan. Namun sambil menunggu keputusan, untuk sementara pihakpihak berikut sudah diperkenankan untuk memanfaatkan tanah tersebut adalah dengan luasan tanah sebagai berikut:

a. Untuk RS. Kusta Kelet seluas 258.600 meter persegi. Dengan perincian 
penggunaan yang diijinkan Gubernur:

- Komplek RS Kusta

: $6.2336 \mathrm{Ha}$.

- Perumahan dinas

- Kebun Kelapa

: 0,5594 Ha.

- Kebun latihan penderita

- Pertokoan

: 5,5016 Ha.

- Perumahan pegawai

$: 3,5429 \mathrm{Ha}$.

$: 0,2351 \mathrm{Ha}$.

- Makam penduduk \& pasien: 0,6410 Ha.

- Gereja

- Balai desa

- SMP Bopkri

- SMP N I, II, III

- Terminal \& Lapangan OR : 3,5700 Ha.

b. Untuk RS Kusta Donorejo seluas 1.806.315 meter persegi. Dengan perincian penggunaan yang diijinkan Gubernur :

- Komplek Rumah Sakit $\quad: 0,4412 \mathrm{Ha}$.

- Kantor dan halaman $\quad: 1,3590 \mathrm{Ha}$.

- Gereja dan Halaman $\quad: 0,2100 \mathrm{Ha}$.

- Rumah Dinas

- Perumahan Karyawan $: 0,0412 \mathrm{Ha}$. : $3,6040 \mathrm{Ha}$.

- Zal dan dapur

- Kuburan

- Sawah

- Kebun Kelapa

- Kebun Randu

- Perkampungan rehabilitasi: $43,6000 \mathrm{Ha}$.

- Stasiun navigasi $\quad: 0,4000 \mathrm{Ha}$.

- Perkampungan sosial $: 5,0008 \mathrm{Ha}$.

- Hutan lindung/sumber air $: 38,2500 \mathrm{Ha}$.

- Obyek wisata \& Benteng Portugis dan kebun kelapa: $7,000 \mathrm{Ha}$

c. Bagi warga yang menempati tanah RS Kusta di Desa Kelet sebanyak 79 KK, dan untuk yang menempati tanah RS Kusta di Donorejo sebanyak $99 \mathrm{KK}$. Mereka belum juga diberi keputusan apakah akan dijinkan untuk memperoleh hak atas tanah yang sudah mereka kuasai secara de facto, namun untuk sementara mereka masih dijinkan untuk menempati sambil menunggu keputusan Gubernur.

\section{Penutup.}

Sebagaimana konflik yang terjadi di Recife yang juga terdapat adanya legal gap dalam memahami hak kepemilikan atas tanah antara masyarakat miskin dengan pengusaha real estate, demikian juga yang terjadi di Jepara sebagaimana dua kasus yang telah dipaparkan di atas. Dari kasus-kasus tersebut terdapat gambaran berbagai macam pilihan untuk menyelesaikan konflik pertanahan apakah pihak yang sebenarnya dirugikan akan memilih pendekatan dengan cara yang dilakukan di Recife (kasus Children's Town), yang dalam prosesnya diiringi dengan tindakan pemaksaan, dan juga protes perlawanan dari warga penghuni liar yang ternyata justru didukung oleh gereja, atau akan memilih model penyelesaian sebagaimana yang terjadi dalam kasus The Skylab, atau Peasant Town di Recife Brazil, atau akan memilih model lokal seperti yang dilakukan oleh Pemerintah Daerah Jawa Tengah di Jepara.

Hal ini adalah persoalan pilihan-pilihan model atau cara penyelesaian hukum yang berdimensi sosial yang terbuka untuk dilakukan. Dari berbagai macam pilihan model penyelesaian konflik kolektif di bidang pertanahan ternyata pendekatan penerapan hukum positif bukanlah satu-satunya cara yang dapat dipakai untuk menyelesaikan konflik. Adakalanya pendekatan hukum positif justru akan mendapatkan perlawanan yang dapat memicu kekerasan baik yang muncul dari pihak yang merasa dikalahkan (masyarakat 
marjinal) ataupun yaing muncul dari pihak pemegang kekuasaan.

Berdasarkan uraian di atas diperlukan untuk membuat gagasan mengenai alternatif resolusi penyelesaian persengketaan kolektif di bidang pertanahan, yang secara ringkas dapat diagendakan menjadi dua bagian yaitu:

1. Agenda Jangka Panjang : diperlukan adanya langkah pembaharuan hukum pertanahan (agrarian reform) yang lebih luas dari pada sekedar melakukan land reform yang lebih berorientasi untuk melindungi kepentingan masyarakat miskin agar mereka tidak mendapatkan kesulitan untuk memperoleh bagian atas kekayaan alam berupa tanah, yang semakin lama semakin sulit dinikmati oleh kaum miskin. Kelompok ini biasanya tidak mempunyai kemampuan untuk mengikuti tuntutan sistem administrasi modern yang dikembangkan dalam sistem administrasi pertanahan modern yang menghendaki adanya bukti formil kepemillkan hak atas tanah.

2. Agenda Jangka Pendek: perlu untuk mengembangkan model alternatif penyelesaian konflik yang saling menguntungkan antara pihak masyarakat miskin dengan pihak pemerintah atau pengusaha. Belajar dari kasus di Recife di Brazil dan di Jepara. Agar penyelesaian kasus persengketaan kolektif di bidang pertanahan tidak berakhir dengan munculnya masalah sosial (berupa keresahan atau bahkan kerusuhan) yang nantinya justru harus dibayar mahal untuk mengatasinya.

\section{Daftar Pustaka}

Boaventura De Sousa Santos, Toward a New Common Sense: Law, Science, and Politics in The Paradigmatic Transition, London Great Britain: Routledge, 1995.

Farida, Mencari Solusi Masalah Sengketa Tanah, Jurnal PSDH 1-2, diambil dari web site http:www.arupa.or.id.

Konsorsium Pembaharuan Agraria, Buku Pegangan Untuk Menilai Proyek Administrasi Pertanahan (Indonesia Land Administration Project), diambil dari web site http:www.geocities.com/ CapitolHill/Lobby/4297/manualap.html Mahfud, Moh. MD. Politik Hukum di Indonesia, Jakarta: LP3ES dan UII Press Yogyakarta, 1998.

Nitiprawiro, Wahono. Teologi Pembebasan: Sejarah, Metode, Praksis, dan Isinya, Yogyakarta: LKIS, 2000.

Usman, Sunyoto. Konflik dan Resolusi Konflik Sumber Daya Alam, Yogyakarta: Gadjah Mada University Press, 2001.

Harian Kompas, terbitan tanggal 3, 6, 11,12, 19 , dan 30 November 2001; tanggal 1 , 6 Desember 2001. 
